\title{
Hand hygiene compliance at neonate intensive care unit in a Brazilian hospital
}

\author{
LR Barbosa ${ }^{1 *}$, MAS Rego ${ }^{2}$, AM Santos $^{3}$, S Colacioppo $^{4}$ \\ From International Conference on Prevention \& Infection Control (ICPIC 2011) \\ Geneva, Switzerland. 29 June - 2 July 2011
}

\section{Introduction / objectives}

Several factors influence compliance to hand hygiene $(\mathrm{HH})$ and different variables can be evaluated to improve quality of care assessment, incentive for performance improvement, outbreak investigation and infrastructure design.

\section{Objective}

To describe the general compliance to $\mathrm{HH}$ associated with variablesof interest in a study of direct observation (DO) in a NeonateÂ Intensive Care Unit (NICU) in a University Public Hospital.

\section{Methods}

DO was performed by 10 observers. Variables were \# beds, \# health care workers, professional category, type of opportunity, day of week, time of the day and product used. Statistical analysis used software Stata and SPSS for Windows.

\section{Results}

A total of 7,324 opportunities for $\mathrm{HH}$ were identified during 2551 hour DO periods from December 2008 to March 2009. Overall compliance rate 50.2\%. 69.5\% for medical doctor (MD), $60.8 \%$ for other professionals (OP), 48.7\% for nurses (RN) representing respectively $10.8 \%, 12 \%$ and $70.3 \%$ of all opportunities. Highest compliance was before aseptic procedure for MD and OP (100\% for both) and after touching patient surroundings for RN (73.1\%). Lowest compliance was after patient contact for all categories: $52 \%(\mathrm{MD}), 42.7 \%(\mathrm{OP})$ and $36.7 \%$ (RN). $55 \%$ of $\mathrm{HH}$ were performed with soap and water, 23.1\% with alcohol-based hand rub (ABHR) and $21.9 \%$ with soap and water followed by ABHR.

'Scientific, GOJO América Latina, São Paulo, Brazil

Full list of author information is available at the end of the article

\section{Conclusion}

DO study results indicated that the NICU did not follow CDC 2002 guideline recommendation for $\mathrm{HH}$. Compliance may be improved by focusing on the opportunities to perform $\mathrm{HH}$ using ABHR products.

\section{Disclosure of interest}

L. Barbosa Employee of Luciana Barbosa is an employee of GOJO América Latina, M. A. Rego: None declared, A. Santos: None declared, S. Colacioppo: None declared.

\section{Author details}

'Scientific, GOJO América Latina, São Paulo, Brazil. ${ }^{2}$ Scientific, Universidade Federal de Minas Gerais, Belo Horizonte, Brazil. ${ }^{3}$ Scientific, Rumel Santos Healthcare Training and Consulting, Calgary, Canada. ${ }^{4}$ Scientific, Universidade de São Paulo, São Paulo, Brazil.

Published: 29 June 2011

doi:10.1186/1753-6561-5-S6-P128

Cite this article as: Barbosa et al:: Hand hygiene compliance at neonate intensive care unit in a Brazilian hospital. BMC Proceedings 2011 5(Suppl 6):P128.

Submit your next manuscript to BioMed Central and take full advantage of:

- Convenient online submission

- Thorough peer review

- No space constraints or color figure charges

- Immediate publication on acceptance

- Inclusion in PubMed, CAS, Scopus and Google Scholar

- Research which is freely available for redistribution 